\title{
Effect of caffeine and coffee diets on calcium signalling in rat hippocampal neurons
}

\author{
V.M. Shkryl ${ }^{1}$, T.G. Turytska ${ }^{2}$, V.A. Yavorsky ${ }^{1}$, V.P. Lyashenko ${ }^{2}$, S.M. Lukashov ${ }^{3}$, \\ E.A. Lukyanetz ${ }^{1}$ \\ ${ }^{1}$ Bogomoletz Institute of Physiology NASU, Kyiv, Ukraine, e-mail: elena@biph.kiev.ua; \\ ${ }^{2}$ Dnipro National Oles Honchar University, Dnipro, Ukraine; \\ ${ }^{3}$ Medical center "Headache", Regional Clinical Hospital N.A. Mechnikov, Dnipro, Ukraine
}

\begin{abstract}
The effects of long-lasting high concentration coffee and caffeine diets on calcium mobilization in rat hippocampal neurons were studied. Changes in the basal calcium level in the hippocampal neurons of control and experimental rats kept on a coffee or caffeine diet were measured. We also recorded the changes in the $\mathrm{Ca}^{2+}$ transients' amplitude evoked by membrane depolarization or emptying the $\mathrm{Ca}^{2+}$ depot of the endoplasmic reticulum (ER) induced by caffeine activator of the ryanodine receptors. In rats on a coffee or caffeine diet, the basal $\mathrm{Ca}^{2+}$ level was increased by $7.4 \%$ and $11 \%$, respectively, compared to control animals. In these groups, the amplitude of $\mathrm{Ca}^{2+}$ transients increased by $70 \%$ and $90 \%$, respectively, of the basal level in response to the membrane depolarization. In the same groups, the amount of $\mathrm{Ca}^{2+}$ released from the ER was increased by two and three times, respectively, compared to the control after activation of ryanodine receptors. We concluded that long-term coffee and caffeine diets in rats cause a significant disruption of the hippocampal neurons' endoplasmic reticulum function. The diets evoke an increase in $\mathrm{Ca}^{2+}$ concentration in the neurons and an excessive release of $\mathrm{Ca}^{2+}$ in response to excitation. The latter can lead to increased excitability of neurons and their further death from excessive $\mathrm{Ca}^{2+}$ levels.

Key words: hippocampal neurons, coffee, caffeine, calcium, ryanodine receptor, endoplasmic reticulum, diet.
\end{abstract}

\section{INTRODUCTION}

Coffee is one of the most consumed beverages globally, with a total consumption of over 5 million tons per year. Consumers prefer coffee because of their taste and stimulating effects [1]. The main coffee component is caffeine, but coffee also includes other compounds such as trigonelline that can affect the nerve function (growth of neurites) [2] or flavonoids [3]. Furthermore, such biologically active substances as chlorogenic acid, catechin, N-methyl pyridine, hydroxytryptamines, pyrogallol, and others were found in the coffee [4]. Thus, coffee and caffeine can cause different effects on the body, taking into account the content of coffee in other biologically active substances.

It has been shown that coffee and caffeine can have both - positive and negative effects on human health. On the one hand, caffeine is used to treat premature bronchopulmonary dysplasia, it may have a protective effect in some diseases such as Parkinson's disease [5], Alzheimer's disease (but not yet fully proven) [6], and for some types of tumors (hepatocyte, endometrial, prostate) [7]. Caffeine can prevent the death of pancreatic cells in alcohol poisoning [8]. Caffeine, also at low doses, reduces cardiovascular diseases, such as coronary artery disease and heart attack. On the other hand, at high doses, it increases the risk of these diseases [9]. Increased coffee/caffeine doses can also cause states such as caffeine addiction, hypertension, insomnia, anxiety states, tachycardia, arrhythmia, migraine, effects on the secretion of gastric juice, and loss of bone tissue, increased intraocular pressure (as a consequence of glaucoma), etc. [10]. The toxic dose is $10 \mathrm{~g}$ of caffeine per day for adults (one coffee cup contains $80-175 \mathrm{mg}$

(C) V.M. Shkryl, T.G. Turytska, V.A. Yavorsky, V.P. Lyashenko, S.M. Lukashov, E.A. Lukyanetz 
of caffeine, depending on the preparation and type of grains). Coffea arabica contains twice as much caffeine as Coffea robusta. The highest content of caffeine is in "Express" coffee (100 $\mathrm{mg} 50 \mathrm{ml}$ ). The use of pure caffeine is more toxic than coffee. Coffee, caffeine, and other coffee ingredients are known to affect brain activity [11]. The coffee component of caffeine is often used as a separate component for stimulating brain activity.

It has been shown that it improves mental activity at a concentration of $3.3 \mathrm{mg} / \mathrm{kg}$ [12]. It is known that caffeine is an activator of ryanodine ER receptors, and it induces $\mathrm{Ca}^{2+}$ release from calcium depots [13]. And thus, coffee and caffeine can affect intracellular calcium homeostasis in neurons and induce different $\mathrm{Ca}^{2+}$-dependent processes, including vesicular trafficking as well they can induce $\mathrm{Ca}^{2+}$-independent processes [14]. In our experiments, we studied the effects of long-lasting coffee and its component caffeine diets on $\mathrm{Ca}^{2+}$ mobilization in rat's hippocampal neurons.

\section{METHODS}

Keeping the Rats on Coffee and Caffeine Diet. The research has been carried out following existing international and Bogomoletz Institute requirements and humane attitude norms towards animals. Experiments were performed on non-linear white male rats, which at the beginning of the study, weighed $0.14 \mathrm{~kg}$. Animals were kept at common sanitary and hygienic conditions with a standard diet. The first group consisted of control animals $(n=6)$, which lived under standard conditions throughout the experiment. The second group $(n=10)$ was represented by animals that were kept with food "Caffeine sodium benzoate" (Darnytsya, UA) in the amount of $150 \mathrm{mg} / \mathrm{kg} /$ day (LD50). Animals of the third group $(n=9)$ daily received a mix of fried coffee beans with food, in $150 \mathrm{mg} / \mathrm{kg} /$ day of pure caffeine weight. The lyophilized powder of coffee was obtained from a commercial blend of coffee beans. According to the International
Institute of Tasting Coffee's recommendation, the mixture was $80 \%$ made up of coffee beans of the Arabica variety and $20 \%$ of the Robusta variety (the mass fraction of caffeine in the mix was $1.48 \%$, which corresponds to GOST 6805 97). In acute experiments, intracellular calcium was measured in the hippocampal neurons in the subgroups of animals, which were taken from the study groups 39 weeks after the beginning of the diets.

\section{Isolation of the neurons of the CA1 region of} the hippocampus

The method of obtaining isolated neurons of the hippocampus of rats in general corresponded to that described in our previous works [1518]. Animals (mature rats) decapitated after anesthesia with ether. The brain was quickly removed and transferred to a cold $\left(4{ }^{\circ} \mathrm{C}\right)$ solution A. The sections of the hippocampus 0.4-0.5 $\mathrm{mm}$ thick were cut using a blade and held for 60 minutes in solution $\mathrm{B}$ at room temperature (21-25 $\left.{ }^{\circ} \mathrm{C}\right)$, placed them on a nylon mesh in a chamber; Aeration of the medium was provided by carbogen. Enzymatic treatment in solution $\mathrm{B}$ of $0.1 \%$ protease (type 23 ) and $0.1 \%$ trypsin (Sigma-Aldrich, USA) lasted 20-35 minutes without changing the medium's temperature. This sequence of processing allowed for the dispersion of sections to receive isolated neurons of the desired zone, which preserved small portions of apical and basal dendrites and had a soma with a diameter of $15 \div 20 \mu \mathrm{m}$ and a length of $30 \div 50 \mu \mathrm{m}$.

Solution A contains (in mmol / 1): NaCl120, $\mathrm{KCl}-5$, HEPES - 10, $\mathrm{MgCl}_{2}-1, \mathrm{CaCl}_{2}-2$, glucose - 25. Solution B: $\mathrm{NaCl}-125, \mathrm{KCl}-5$, $\mathrm{NaH} 2 \mathrm{PO}_{4}-1.25, \mathrm{NaHCO}_{3}-25, \mathrm{MgCl}_{2}-1$, $\mathrm{CaCl}_{2}-2$, glucose - 10. All substances obtained from Sigma-Aldrich Company, USA.

\section{Measurement of intracellular calcium}

Intracellular calcium was measured as it was described previously [19-22]. Briefly, immediately before the experiment, the neurons' staining in a solution of fluorescent dye Fura- 
$2 \mathrm{AM}(5 \mu \mathrm{M})$ was performed for 20 minutes. Then the glass coverslips with the neurons were placed in the experimental chamber. The experimental chamber was installed on a fluorescence microscope and a solution flow system, washing the cells with the solution and changing it to apply the factors. Depolarization of the membrane was carried out using $5 \mathrm{~s}$ application of $50 \mathrm{mM} \mathrm{KCl}$ solution, and $5 \mathrm{~s}$ application of $20 \mathrm{mM}$ caffeine was used to release calcium from the endoplasmic depot.

Changes in the level of fluorescence intensity in neurons were recorded with an experimental digital video camera at excitation wavelength 340 and $380 \mathrm{~nm}$. Using computer software Cell M software (Olympus, Japan) and IDL programming environment (ITT Visual Information Solutions), further data analysis was performed, and the ratio of fluorescence intensity in the range of $340 \mathrm{~nm}$ fluorescence to $380 \mathrm{~nm}$ ( $\mathrm{R}=\mathrm{F} 340 / \mathrm{F} 380)$ was calculated. Dynamic changes in this indicator evaluated changes in the level of free calcium in the cytosol of neurons.

\section{Experimental solutions}

Basic solution used as a perfusion solution in the experimental chamber: $\mathrm{NaCl}-140 \mathrm{mM}$; $\mathrm{KCl}$ - $2 \mathrm{mM}$; $\mathrm{CaCl} 2$ - $2 \mathrm{mM}$; $\mathrm{MgCl} 2-2.0 \mathrm{mM}$; HEPES-10 mM, pH 7.4. To depolarize the neuronal membrane and induction of calcium transitions in this way, a high-potassium solution $(50 \mathrm{mM} \mathrm{KCl})$ was used: $\mathrm{NaCl}-82 \mathrm{mM} ; \mathrm{KCl}-50$ $\mathrm{mM}$; $\mathrm{CaCl}$ - 2MM; $\mathrm{MgCl} 2-2.0 \mathrm{mM}$; HEPES-10 $\mathrm{mM}, \mathrm{pH}$ 7.4.

\section{Statistical analysis}

Numerical data were subjected to statistical processing (Investigator criterion) using Origin software (OriginLab Corporation, USA). Intersample differences with $\mathrm{P}<0.05$ were considered statistically significant.

\section{RESULTS}

In all neurons, measurements of free calcium levels were performed during short-term cellular stimulation (5 s) with the high-potassium solution. After calcium level recovery to the basal level, stimulation was repeated. Then, after the basal level's restoring, we made a short-term application of solution with $20 \mathrm{mM}$ caffeine (5 s).

The application of high-potassium solution causes depolarization of the neuronal membrane, which leads to the influx of calcium ions through voltage-sensitive calcium channels in the cell. Also, this process contributes to the filling of intracellular calcium depots in the neurons. Caffeine is an agonist of the ryanodine receptor calcium channel of the endoplasmic reticulum (ER), and therefore its application causes the release of calcium from ER. It was found that $53.6 \%$ of the neurons from the control group $(\mathrm{n}=28)$ responded to stimulation with the highpotassium solution.

In the neurons of the control group, the basal calcium level measured in relative units (F340/ F380) was $1.36 \pm 0.04(\mathrm{n}=28$; all investigated neurons) and $1.30 \pm 0.07(\mathrm{n}=15$, corresponding to high-potassium solution). An example of changes in the intracellular level of $\mathrm{Ca}^{2+}$ that occurred due to these stimuli in the neuron in control animals is shown in Fig. 1. 54.2\% of the neurons from the coffee group animals $(n=24)$ and $30.4 \%$ of the caffeine group $(n=23)$ responded to stimulation by a high-potassium solution. In the neurons of the caffeine group, the level of free basal calcium was $1.46 \pm 0.07$ $(\mathrm{n}=23$; all studied $)$ and $1.20 \pm 0.06(\mathrm{n}=7$; responding to high-potassium solution). In the coffee group's neurons, the level of free basal calcium was $1.51 \pm 0.09(\mathrm{n}=24$; all investigated $)$ and $1.45 \pm 0.09(\mathrm{n}=7$; responding to high-potassium solution). Changes in the intracellular level of calcium in animals of the coffee group, in response to stimulation of the high-potassium solution and caffeine, are shown in Fig. 2

It was also found that the amplitude of calcium transient $(\Delta \mathrm{R}$, ratio $\mathrm{F} 340 / \mathrm{F} 380)$ in response to high-potassium solution was 0.10 $\pm 0.02(\mathrm{n}=15) ; 0.17 \pm 0.06(\mathrm{n}=7)$ and $0.19 \pm$ 


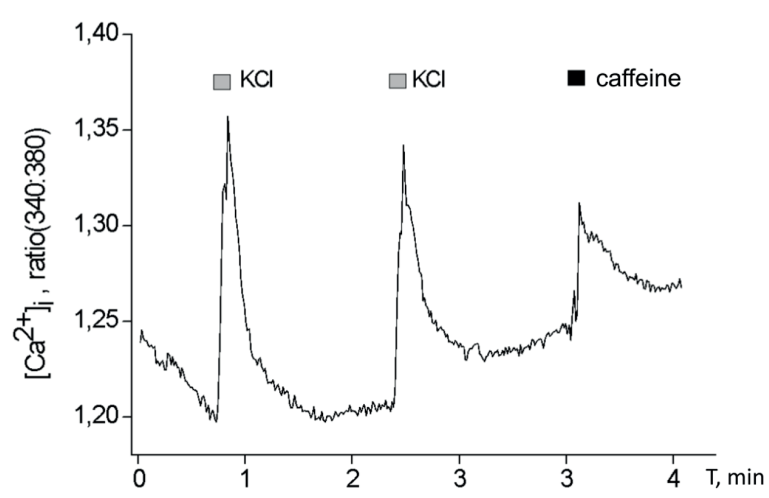

Fig. 1 Selective registration of changes in the intracellular concentration of free calcium in the neuron from the animals' control group

$0.05(\mathrm{n}=13)$ from the basal level, respectively, in the control group, caffeine and coffee groups, as shown in the diagram in Fig. 3

In Fig. 4 is a graph of statistical data on the amount of calcium release from the endoplasmic depot. The amount of calcium released from the ER was evaluated as the amplitude of the calcium transient from the basal level $(\Delta \mathrm{R}=$ F340 / F380; when applying a solution of 20 $\mathrm{mM}$ of caffeine). In the control group, this value was $0.06 \pm 0.01(n=5)$. In the caffeine and coffee groups' animals, the amount of calcium released from the ER was increased compared

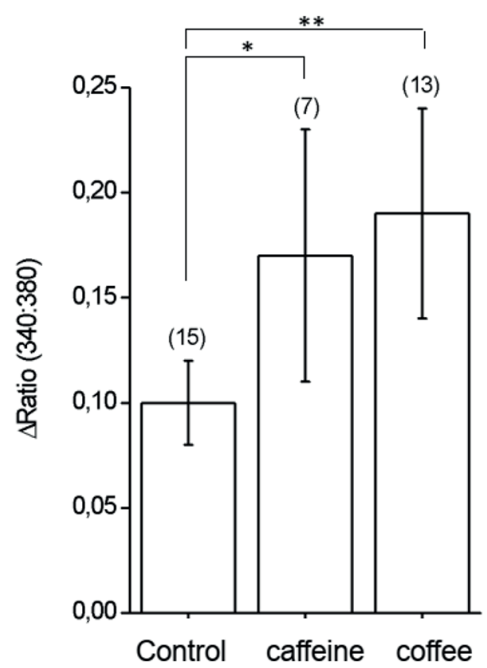

Fig. 3 The amplitude of calcium transient was evoked by the application of a high-potassium solution in different groups of rats. Designations here and in other figures $(\mathrm{P}<0.05 *$, $\mathrm{P}<0.01 * *)$

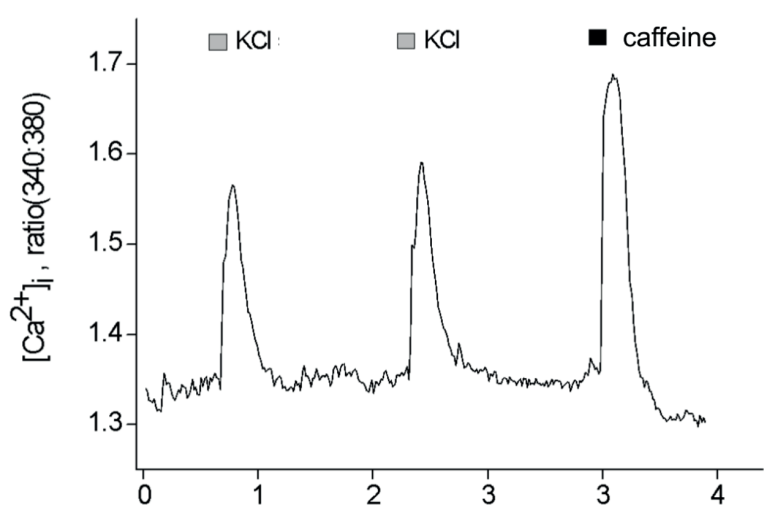

Fig. 2 Selective registration of changes in the intracellular concentration of free calcium in the neuron from the coffee group's animals

to the control and amounted to $0.12 \pm 0.04(\mathrm{n}=5)$ and $0.19 \pm 0.06(\mathrm{n}=8)$, respectively.

\section{DISCUSSION}

Coffee, caffeine, and other coffee ingredients are known to affect brain activity [11]. I.P. Pavlov and his collaborators have yet investigated the physiological features of caffeine's action on the central nervous system. They showed that caffeine enhances and regulates the processes of excitation in the cerebral cortex. They demonstrated that caffeine enhances and regulates the processes of excitation in

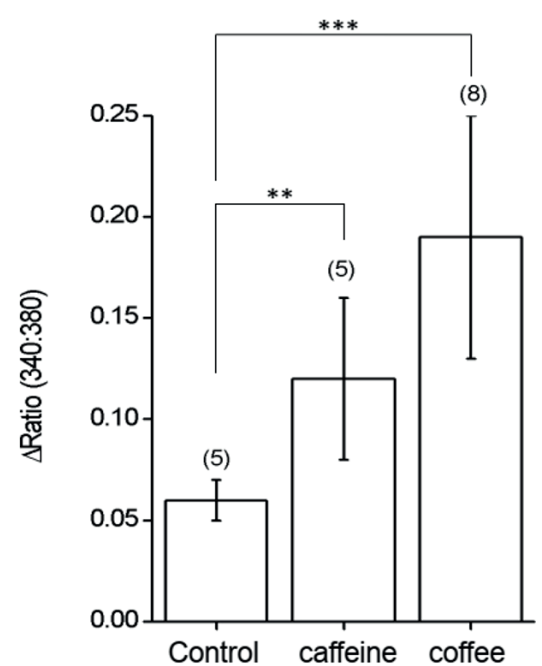

Fig. 4 The amplitude of calcium transient was evoked by applying a solution containing $20 \mathrm{mM}$ of caffeine in different rats' groups 
the cerebral cortex. In corresponding doses, it enhances positive conditioned reflexes and enhances motor activity. Stimulating action leads to increased mental and physical efficiency, reducing fatigue and drowsiness. However, large doses can lead to exhaustion of nerve cell state.

Recent data indicate that coffee (Coffea arabica or Coffea canephora var. robusta) caused an increase in the excitatory neurotransmitter effect on the accumulation of calcium and the release of dopamine in PC12 cells [4]. The release of neurotransmitters or exocytosis is regulated by the concentration of $\mathrm{Ca}^{2+}$ ions, which play an essential role in the outflow of neurotransmitters during synaptic transmission [23-25]. Besides, the release of $\mathrm{Ca}^{2+}$ from the intracellular depot also takes part in synaptic transmission regulation. Thus, the presence of ryanodine receptors in the hippocampal neurons' presynaptic endings was demonstrated [26-29].

Caffeine, which belongs to the group of methylxanthines, has a chemical name: 1,3,7-trimethyl-xanthine. Like methylxanthines, it can be an antagonist of adenosine receptors [30], causing the release of neurotransmitters [4, 31]. It was shown that caffeine is an antagonist of all types of adenosine receptors - A1, A2A, A3, and A2B [32]. Caffeine also inhibits phosphodiesterases (PDE1, PDE4, PGE5), interferes with GABA-A receptors, and has an influence on several brain diseases, including Alzheimer's disease [32]. Nevertheless, many of these processes are associated with the ER's functioning - for example, the receptor-activated release of neurotransmitters and other calciumdependent processes that occur in the cell. The latter is due to the ability of caffeine also to affect directly intracellular $\mathrm{Ca}^{2+}$ depots of the ER. Calcium processes associated with ER are also influenced by other active components isolated from other plants, such as Taraxacum officinale [33]. This plant is also used to make tipping drinks. Also, other natural products can act on the ER and interfere with ER stress [3].

It is known that two types of ER are inositol trisphosphate (IP3R) and ryanodine receptors (RyR). These receptors cause a rapid $\mathrm{Ca}^{2+}$ leakage from SR/ER, increasing $\mathrm{Ca}^{2+}$ in the cytosol, and triggering a series of signaling processes. Caffeine is an activator of ryanodine ER receptors, and its activation causes $\mathrm{Ca}^{2+}$ release from ER [34]. In turn, it is known that ER disfunction can promote a number of disorders of nervous system [35]. In our studies, we aimed to investigate the only one aspect of caffeine and coffee action through corresponding diet their prolong effect on RyR-receptors of ER of hippocampal neurons.

Our experiments showed that basal $\mathrm{Ca}^{2+}$ levels in neurons of rats with long-term coffee or caffeine diet increased by $7.4 \%$ and $11 \%$, respectively, compared with control animals. In animals of the caffeine and coffee groups, the amplitude of calcium transient in response to high-potassium solution increased by $70 \%$ and $90 \%$, respectively, of the basal level. It turned out that in the same groups, the amount of calcium released from ER after activation of the ryanodine receptors was increased two and three times, respectively, in comparison with the control animals. Thus, it is concluded that long-term caffeine and coffee diets in rats cause a significant violation of ER's activity in the hippocampal neurons, namely, an increase in the basal level of $\mathrm{Ca}^{2+}$ in the cell and excessive calcium release in response to irritation. The latter can lead to increased excitability of neurons and their death from excessive calcium levels.

Summing up, our results point that longterm caffeine and coffee diets in rats cause a significant violation of ER's activity in the hippocampal neurons, namely, an increase in the basal level of $\mathrm{Ca}^{2+}$ in the cell and excessive calcium release in response to irritation. The latter can lead to increased excitability of neurons and their death from excessive calcium levels.

\section{Acknowledgements}

This study was supported by National Acade- 
my of Sciences of Ukraine (NASU) SRN 0118 U007344 and NASU to support the development of priority areas of research SRN (state registration number) 0120U001281

The authors of this study confirm that the research and publication of the results were not associated with any conflicts regarding commercial or financial relations, relations with organizations and/or individuals who may have been related to the study, and interrelations of co-authors of the article.

\section{Ethical Approval}

The experiments were approved by Local Ethics Committee at Bogomoletz Institute of Physiology, NAS of Ukraine.

\section{В.М. Шкриль ${ }^{1}$, Т.Г. Турицька ${ }^{2}$, В.А. Яворський ${ }^{1}$, В.П. Ляшенко ${ }^{2}$, С.М. Лукашов ${ }^{3}$, О.О. Лук'янець ${ }^{1}$ \\ ВПЛИВ КОФЕЇНУ ТА КАВОВОЇ ДІЄТИ НА СИГНАЛІЗАЦЮЮ КАЛЬЦІЮ В ГІПОКАМПАЛЬНИХ НЕВРОНАХ ЩУРА}

${ }^{1}$ Інститут фізіології ім. Богомольия НАН України, Київ;

2 Дніпровський начіональний університет імені Олеся Гончара, Дніпро;

${ }^{3}$ Медичний ичентр «Головний біль», Обласна клінічна лікарня ім. Мечникова, Дніпро

Вивчено вплив тривалої дієти 3 високою концентрацією кави та кофеїну на мобілізацію кальцію в нейронах гіпокампа щурів. Вимірювали зміни базального вмісту кальцію в нейронах гіпокампа контрольних та до щурів, яких утримували на кавовій або кофеїновій дієті. Зафіксовано зміни амплітуди $\mathrm{Ca}^{2+}$-транзієнтів, які викликані деполяризацією мембрани або спорожненням $\mathrm{Ca}^{2+}$-депо ендоплазматичного ретикулума (ЕР), індукованого кофеїном, активатором ріанодинових рецепторів. У щурів, які перебували на кавовій або кофеїновій дієті, базальний вміст $\mathrm{Ca}^{2+}$ був збільшений на 7,4 та $11 \%$ відповідно порівняно 3 контрольними тваринами. У цих групах амплітуда $\mathrm{Ca}^{2+}$-транзієнтів зросла на 70 та 90\% відповідно від базового рівня у відповідь на деполяризацію мембрани. Вміст $\mathrm{Ca}^{2+}$, що виділяється 3 $\mathrm{EP}$, у них збільшилась у 2 та 3 рази відповідно порівняно 3 контролем після активації ріанодинових рецепторів. Ми дійшли висновку, що тривале харчування кавою або кофеїном у щурів спричиняє значне порушення функції ендоплазматичного ретикулума нейронів гіпокампа. Ці дієти викликають збільшення концентрації $\mathrm{Ca}^{2+}$ у нейронах та надмірне його виділення у відповідь на збудження. Останнє може призводити до підвищеної збудливості нейронів та подальшої їх загибелі від надмірного вмісту $\mathrm{Ca}^{2+}$.

Ключові слова: нейрони гіпокампа; кава; кофеїн; кальцій; ріанодиновий рецептор; ендоплазматичний ретикулум; дієта.

В.М. Шкрыль, Т.Г. Турицька, В.А. Яворский, В.П. Ляшенко, С.М. Лукашов, Е.А. Лукьянец

ВЛИЯНИЕ КОФЕИНА И КОФЕЙНОЙ ДИЕТЫ НА СИГНАЛИЗАЦИЮ КАЛЬЦИЯ В ГИПОКАМПАЛЬНИХ НЕВРОНАХ КРЫСЫ

Изучено влияние длительной диеты с высокой концентрацией кофе и кофеина на мобилизацию кальция в нейронах гиппокампа крыс. Измеряли базальное содержание кальция в нейронах гиппокампа контрольных и крыс, которые содержались на кофейной или кофеиновой диете. Были зафиксированы изменения в амплитуде $\mathrm{Ca}^{2+}$-транзиентов, вызванные деполяризацией мембраны или опорожнением $\mathrm{Ca}^{2+}$-депо эндоплазматического ретикулума (ЭР), индуцированного кофеином, активатором рианодиновых рецепторов. У крыс, которые придерживались кофейной или кофеиновой диеты, базальное содержание $\mathrm{Ca}^{2+}$ было увеличено на 7,4 и $11 \%$ соответственно по сравнению с контрольными животными. В этих группах амплитуда $\mathrm{Ca}^{2+}$-транзиентив выросла соответственно на 70 и $90 \%$ от базового уровня в ответ на деполяризацию мембраны. Содержание $\mathrm{Ca}^{2+}$, который выделяется из ЭР, увеличилось в 2 и 3 раза соответственно по сравнению с контролем после активации рианодиновых рецепторов. Мы пришли к выводу, что длительная диета, содержащая кофе или кофеин, у крыс вызывает значительное нарушение функции ЭР нейронов гиппокампа, увеличение концентрации $\mathrm{Ca}^{2+}$ в нейронах и чрезмерное его выделение в ответ на возбуждение. Последнее может приводить к повышенной возбудимости нейронов и последующей их гибели от чрезмерно высокого содержания уровня $\mathrm{Ca}^{2+}$. Ключевые слова: нейроны гиппокампа; кофе; кофеин; кальций; рианодиновый рецептор; эндоплазматический ретикулум; диета.

\section{REFERENCES}

1. Geel L, Kinnear M, De Kock R. Relating consumer preferences to sensory attributes of instant coffee. Food Quality and Preference. 2005;16:237-44.

2. Tohda C, Nakamura N, Komatsu K, Hattori M. Trigonellineinduced neurite outgrowth in human neuroblastoma SK-N-SH cells. Biological \& pharmaceutical bulletin. 1999;22(7):679-82.

3. Martucciello S, Masullo M, Cerulli A, Piacente S. Natural Products Targeting ER Stress, and the Functional Link to Mitochondria. Int J Mol Sci. 2020;21(6):1905.

4. Walker J, Rohm B, Lang R, Pariza MW, Hofmann T, Somo- 
za V. Identification of coffee components that stimulate dopamine release from pheochromocytoma cells (PC-12). Food and Chemical Toxicology. 2012;50(2):390-8.

5. Noyce AJ, Bestwick JP, Silveira-Moriyama L, Hawkes $\mathrm{CH}$, Giovannoni G, Lees AJ, et al. Meta-analysis of early nonmotor features and risk factors for Parkinson disease. Ann Neurol. 2012;72(6):893-901.

6.Panza F, Solfrizzi V, Barulli MR, Bonfiglio C, Guerra $\mathrm{V}$, Osella A, et al. Coffee, tea, and caffeine consumption and prevention of late-life cognitive decline and dementia: a systematic review. The journal of nutrition, health \& aging. 2015;19(3):313-28.

7. Cano-Marquina A, Tarín JJ, Cano A. The impact of coffee on health. Maturitas. 2013;75(1):7-21.

8. Petersen $\mathrm{OH}$, Sutton R. Ca2+ signalling and pancreatitis: effects of alcohol, bile and coffee. Trends in pharmacological sciences. 2006;27(2):113-20.

9. Ding M, Bhupathiraju SN, Satija A, van Dam RM, Hu FB. Long-term coffee consumption and risk of cardiovascular disease: a systematic review and a dose-response metaanalysis of prospective cohort studies. Circulation. 2014;129(6):643-59.

10. Hensher C, Vogel J. High-Dose Insulin Euglycemic Therapy in the Treatment of a Massive Caffeine Overdose. Chest. 2020;157(5):e145-e9.

11.Fernstrom JD. Can nutrient supplements modify brain function? The American journal of clinical nutrition. 2000;71(6 Suppl):1669s-75s.

12. Battig K, Welzl H. Psychopharmacological profile of caffeine. In: Garattini S, editor. Caffeine, coffee, and health. Monographs of the Mario Negri Institute for Pharmacological Research, Milan. New York: RavenPress; 1993. p. 213-53.

13. Segal M. Calcium stores regulate excitability in cultured rat hippocampal neurons. Journal of neurophysiology. 2018;120(5):2694-705.

14. Dobson KL, Jackson C, Balakrishnan S, Bellamy TC. Caffeine Modulates Vesicle Release and Recovery at Cerebellar Parallel Fibre Terminals, Independently of Calcium and Cyclic AMP Signalling. PloS one. 2015;10(5):e0125974.

15. Yavorsky VA, Lukyanetz EA. Using the serial ramp recordings for rapid testing of the generating ability of impulse activity of isolated hippocampal neurons. Fiziolohichnyi zhurnal (Kiev, Ukraine : 1994). 2015; 61(3):19-27.

16. Yavorsky VA, Lukyanetz EA. Pilocarpine-induced epileptiform activity of isolated CA1 hippocampal neurons. Neurophysiology. 1997;29(3):162-7.

17. Yavorsky VA, Lukyanetz EA. Interspike model of neuronal impulse activity. Fiziol Zh. 2009;55(6):135.

18. Lukyanetz IA, Kostyk PG, Lukyanetz EA. Calcium Signaling in Carassius Cerebellar Neurons: Role of the Mitochondria. Neurophysiology. 2009;41(6):375-9.

19. Lukyanets IA, Lukyanetz EA. Modulation of calcium signalling by the endoplasmic reticulum in Carassius neurons. Biochem Biophys Res Commun. 2013;433(4):591-4.

20. Lukyanets IA, Lukyanetz EA. Calcium signalling during hypoxia in fish Carasius gibelio. Fiziol Zh. 2009;55(6).
21. Rozumna NM, Shkryl VM, Ganzha VV, Lukyanetz EA. Effects of Modeling of Hypercalcemia and $\beta$-Amyloid on Cultured Hippocampal Neurons of Rats. Neurophysiology. 2020;52(5):348-57.

22. Shkryl VM. Error correction due to background subtraction in ratiometric calcium measurements with $\mathrm{CCD}$ camera. Heliyon. 2020;6(6):e04180.

23. Lukyanetz EA, Neher E. Different types of calcium channels and secretion from bovine chromaffin cells. European Journal of Neuroscience. 1999;11(8):2865-73.

24. Lukyanetz EA. Different secretory vesicles can be involved in depolarization-evoked exocytosis. Biochemical and Biophysical Research Communications. 2001;288(4):844-8.

25. Lukyanetz EA. Calcium signaling in secretion of catecholamines in chromaffin cells. Fiziol Zh. 2009; 55(6):110-1.

26. Lauri SE, Bortolotto ZA, Nistico R, Bleakman D, Ornstein PL, Lodge D, et al. A role for $\mathrm{Ca}^{2+}$ stores in kainate receptor-dependent synaptic facilitation and LTP at mossy fiber synapses in the hippocampus. Neuron. 2003;39(2):327-41.

27. Liang Y, Yuan LL, Johnston D, Gray R. Calcium signaling at single mossy fiber presynaptic terminals in the rat hippocampus. Journal of neurophysiology. 2002;87(2):1132-7.

28. Sato I, Kamiya H. Assessing the roles of presynaptic ryanodine receptors and adenosine receptors in caffeineinduced enhancement of hippocampal mossy fiber transmission. Neuroscience research. 2011;71(2):183-7.

29. Shimizu H, Fukaya M, Yamasaki M, Watanabe M, Manabe T, Kamiya H. Use-dependent amplification of presynaptic $\mathrm{Ca}^{2+}$ signaling by axonal ryanodine receptors at the hippocampal mossy fiber synapse. Proceedings of the National Academy of Sciences of the United States of America. 2008;105(33):11998-2003.

30. Wood PL, Kim HS, Boyar WC, Hutchison A. Inhibition of nigrostriatal release of dopamine in the rat by adenosine receptor agonists: A1 receptor mediation. Neuropharmacology. 1989;28(1):21-5.

31. Solinas M, Ferré S, You ZB, Karcz-Kubicha M, Popoli P, Goldberg SR. Caffeine induces dopamine and glutamate release in the shell of the nucleus accumbens. The Journal of neuroscience : the official journal of the Society for Neuroscience. 2002;22(15):6321-4.

32. Ribeiro JA, Sebastião AM. Caffeine and adenosine. Journal of Alzheimer's disease : JAD. 2010;20 Suppl 1:S3-15.

33. Gerbino A, Russo D, Colella M, Procino G, Svelto M, Milella L, et al. Dandelion Root Extract Induces Intracellular $\mathrm{Ca}(2+)$ Increases in HEK293 Cells. Int J Mol Sci. 2018;19(4):1112.

34. Thomas RC. Calcium content of the endoplasmic reticulum of snail neurones releasable by caffeine. Cell Calcium. 2013;53(2):120-4.

35. Stutzmann GE, Mattson MP. Endoplasmic reticulum $\mathrm{Ca}(2+)$ handling in excitable cells in health and disease. Pharmacol Rev. 2011;63(3):700-27.

Received 14.07.2021 